\title{
Clusters in the Industrial Policy and Spatial Development of Russia
}

\author{
Robert O. Voskerichyan \\ Faculty of Economy \\ Peoples Friendship University of Russia (RUDN University) \\ Moscow, Russian Federation \\ voskerichyan_ro@rudn.university
}

\begin{abstract}
This paper is about the role of clusters in industrial policy of Russia. The experience of foreign countries is presented and the main directions of development of the national industry are also considered. Besides, the relationship between the development of technological clusters and the growing competitiveness of the Russian economy are revealed. The influence of clusters on the spatial development of Russia and various approaches and models of central government's activity aimed at correction of disproportions in the development of various subjects of the Russian Federation are investigated.
\end{abstract}

Keywords-industrial policy, cluster, investment, innovation system, spatial development, subject of the Russian Federation

\section{INTRODUCTION}

The current period is characterized by significant changes in industrial policy of Russia. One of the most important of them is creation of clusters in various regions. This process gives an opportunity both to develop national industry and even the levels competitiveness of various subjects of Russia.

\section{MATERIALS AND METHODS}

\section{A. Literature Review}

The concept of "cluster" was introduced into widespread use in the late 1980s, and was expecting a group of geographically adjacent interconnected companies and associated institutions that need to operate in a certain area, characterized by common activities and complements each other.

Alfred Marshall [1] was the first economist who commented the relational communications between companies and entire industries.

Michael Porter [2] proposed a theory about the importance of creating clusters in economic development.

The problem of the cluster approach in Russia is studied by scientists such as Yakovlev Andrei, Granberg Alexander, Yasin Yevgeniy and other scientists.

\section{B. Description of the Problem}

At present, Russia is implementing a program of industrial clusters creation and development [3]. The project is designed to involve industrial small and medium-sized enterprises.

The publication was financially supported by the Ministry of Education and Science of the Russian Federation (the Agreement number 02.a03.0008)
In their business, these enterprises will be launched on a competitive basis by large companies. In practice, it will look like this: according to the results of the tender, a small enterprise will receive an order from a large company and will be obliged to execute it on time. In this case, the executor can take a loan, get equipment leased. This will not be a holding within the framework of one economic entity; it is a commonwealth of various economic entities. Small and medium-sized enterprises will occupy a dominant role there. Competing, entrepreneurs will apply innovations and reduce their costs. As a result, the products will be the best in quality and price.

Each region where clusters are created has two or three directions for developing production. One of the first projects was created in Irkutsk. There it was decided to involve small businesses in the aviation industry. These enterprises need not be focused on aviation; they can take orders from subcontractors in other industries. It is also planned to create several metal processing enterprises in the Irkutsk Region.

In the future, it is possible to create clusters in other industries. The cluster system will work in the field of human health and recreation. Such projects will be launched in Tver and Krasnodar. Clusters can also work within the framework of the project for the development of information technology enterprises, which is being prepared in Dubna.

The most important advantage of science-intensive industries in Russia - scientific and technological backlog - is not eternal. It is not a natural competitive advantage of the country. If the raw materials industry retains positions in the coming decades, there is no such certainty about the future, for example, of the aerospace industry.

The maintenance and development of the scientific and technical base depends on the effectiveness of the state's industrial policy [4]. This leads to a new approach to the choice of "poles of growth."

In assessing the competitiveness of national economies, an increasingly important role is played by the technological approach. Competitiveness is based on aggregation of three indices characterizing the state of technology, public institutions, and the macroeconomic environment [5].

Technological clusters are able to become the "poles of technological growth" in the modern world. Their creation is one of the important steps on the path of successful economic 
development. Examples include clusters that unite information technology companies in the Silicon Valley in the United States and telecommunications companies in Espoo in Finland.

Clusters are rarely subject to standard industry classification systems. They usually consist of companies from several industries that produce finished products, materials and equipment, as well as those involved in the service. Public and private investments aimed at improving the operating conditions of the cluster, benefit many companies at once.

In some ways, the choice of technological clusters is similar to the choice of a list of critical technologies. Such lists in different countries were compiled with varying degrees of success.

Summarizing domestic and foreign experience, it is possible to single out a list of technological clusters that will have a significant impact on the competitiveness of the country's economy: nanotechnology, biotechnology, new materials information technologies.

A distinctive feature of technological clusters is that specific technologies developed here can find application in the most various branches, including in raw materials and processing, strengthening their competitive positions.

"Parallel" definition of today's competitive industries and technological clusters of tomorrow allows us to reach out to the formulation of the optimal strategy for Russia's economic development.

In fact, the country is carrying out a resource-export strategy aimed at exporting primary resources. Certain hopes have been placed on an export-science-intensive strategy that involves a significant increase in the supply of Russian science-intensive products to the world market. However, these hopes are not justified: there are no real competitive advantages for Russia in this sphere (except for military products), and "fine-tuning" to commercial use of existing technological reserves would require enormous investments, which are not yet available.

Combines the advantages of these two strategies the third way - resource-innovation strategy. It relies on the coordinated and fuller use of domestic resource and innovation potential by supporting long technological chains, including through technology clusters.

At the same time, the state with its regulatory and legal framework should stimulate the efficiency of the use of capital and human resources, and its aggregate power - to ensure the interests of national producers in the global market, far from free and not fair. The authorities are objectively interested in supporting domestic producers, promoting their development and prosperity, since there is an inextricable link between the competitiveness of the business sector and the level of the country's competitiveness [6].

Among the factors of competitiveness of developed countries, the most important are the infrastructure (energy, transport, communications, and health), the financial system (the amount of capital that can be used to finance industry and other sectors of the economy), the resource of scientific knowledge in universities, state research institutes, Private research institutions. All these factors can be involved in the implementation of the cluster approach.

In Russia, this approach sometimes remains beyond the attention, although a number of formally unformed clusters are already operating in the country: transport engineering in the Central Federal District, timber processing in the Arkhangelsk region, automotive industry in Togliatti, aerospace cluster in Samara, information technology cluster In the Moscow region. To support existing clusters and promote the emergence of new ones is the real task of Russia's modern industrial policy.

Thus, the cluster is an effective instrument of industrial policy. A tool that allows you to include small businesses in the industrial technology chain and solve many problems at the regional level. New jobs for the population. Working infrastructure for the small business. Information on the availability of reliable and commercial effective projects for potential investors. New sources of financing of capital investments in territorial development for local and regional authorities. Macroeconomic and social dividends to the federal government. Only enumeration of possible advantages, in our opinion, is enough to assess the scale of the phenomenon.

The specific actions of the federal government are needed: activities, targeted programs, legislative initiatives to stimulate initiatives at the regional and local levels. Specific measures of the subjects of the Federation: the completion of technological chains, the formation of new structures (for example, educational), the stimulation of modernization. Specific actions of business associations: information exchange, coordination, building processes, participation in the definition of common standards. Effective economic development is the fruit of joint efforts. And these efforts should be aimed at the final result - the increase in sales of competitive products [7].

At present, in Russia, according to our estimates, only about $6 \%$ of industrial enterprises can be characterized as innovative-active (Fig. 1).

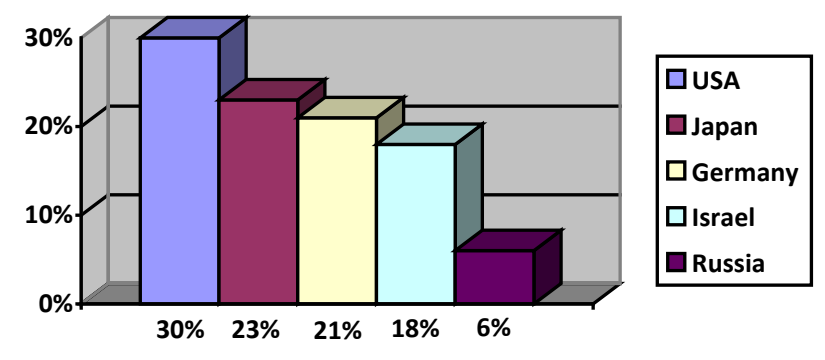

Source: compiled by the author

Fig. 1. Percentage share of innovative industrial enterprises (2016)

The creation of industrial districts and clusters allowed developed countries to mobilize a new resource - the network organization of territories. This resource becomes the basis of competitiveness in the global economy (Fig. 2). 


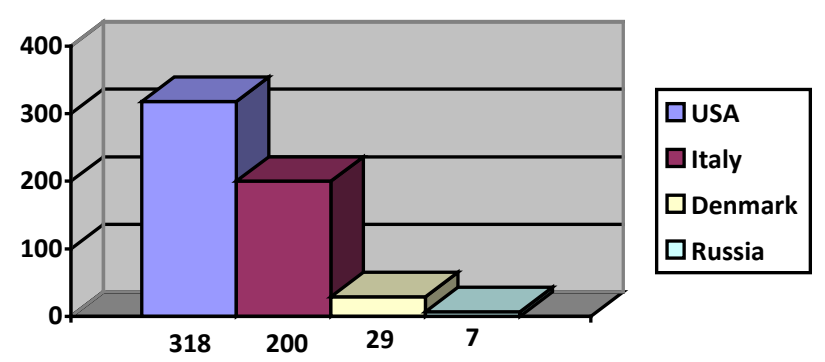

Source: compiled by the author

Fig. 2. Amount of territorial clusters in national industry (2016)

That is why the gap between subjects of the Russian Federation is growing (Fig. 3).

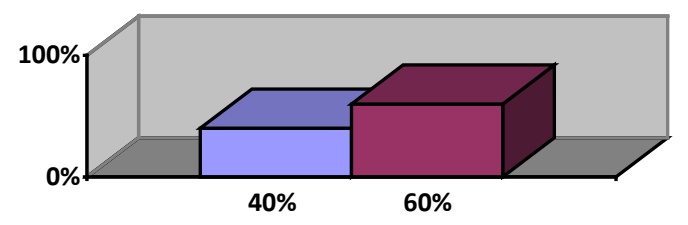

$\square 73$ subjects of the Russian Federation

$\square 12$ subjects of the Russian Federation (including Moscow, Saint Petersburg, Republic of Tatarstan, Krasnoyarsk, Samara and Tyumen regions)

Source: compiled by the author

Fig. 3. Percentage share in Gross Domestic Product (GDP) of Russia (2016)

\section{RESULTS}

Of course, in Russia there are serious limitations of cluster policy, because as a result of the Soviet policy of locating productive forces, about a quarter of all subjects of the Russian Federation have a single-industry economy, where major corporations are the main donor of budgets.

Nevertheless, state power, private business, and the scientific community are equally interested in accelerating the development of innovation infrastructure.

Foreign industrial business is already showing interest in the collective activities of federal and regional authorities, scientific organizations for organizing and financing industrial districts on the territory of the Russian Federation. This is starting to be done by Russian investors, but so far only a few are able to act in this direction while private business initiatives to develop innovative infrastructure are not motivated by legislation.

The development of a network of industrial districts and clusters has a direct bearing on the problem of a new regional policy. Currently, at the federal level, the concept is dominant, according to which the center rejects the policy of equalizing the socio-economic development of the regions in favor of outstripping development of the territories that can become the "locomotives" of growth for the country's economy.

According to this concept, the current system of supporting the territories needs to be changed. Polarization is growing, despite all federal targeted programs, leveling the revenues of the territories. In addition, the "leader regions" lose their motivation for development.

In several regions, which will become "growth locomotives", it is proposed to concentrate financial, administrative and administrative resources, and the remaining territories - to give money only to the social sphere. The criteria by which "locomotives" can be singled out are as follows: these territories should make a significant contribution to gross domestic product, they must establish a strategic partnership between government and business, and for the neighbors these regions are able to become "developers".

In addition to Moscow and St. Petersburg, groups of powerful regions can reach this level of development in the Urals, Siberia and the Far East.

However, if the state completely abandons the policy of equalization, the Russian Federation may face a huge gap in the standard of living of people, and this is fraught with a split in the country.

The presented concept is based on the well-known theory of centre-peripheral development in the regionalist theory. Its essence is very short in the following. Economic growth is concentrated in the poles of growth (usually in large cities) due to the fact that they have certain competitive advantages (developed infrastructure, skilled personnel, capacious consumer market, and the availability of scientific and educational centers). The territories adjacent to the poles of growth are developed due to the positive influence of the leaders: the periphery begins to produce products for the markets of the poles of growth, on the periphery production is carried out for the sake of saving on costs. In Russia, Moscow and its surrounding regions are an example of really working centrally-peripheral relations.

Since centrally-peripheral relations are an objective reality in the world economy, in many countries they are taken into account in the development of regional policy, singling out poles of growth as its objects. In this way, for example, in Germany, when developing the concept of the development of eastern lands after the unification of the country [7].

However, with reference to Russia, the focus on centrallyperipheral relations faces one basic problem. This concept works well with a fairly high population density and a uniform distribution of large cities across the country. In the case of huge distances, the presence of a vast periphery and a shortage of infrastructures (as in Russia), it is extremely difficult to involve this periphery in the sphere of influence of the growth poles or to isolate the future poles of growth in the periphery itself [8]. And this problem has not been solved yet. For example, in the Far East and the Trans-Baikal region, no region is defined as the locomotive: the east of the country lags behind in terms of growth rates, experiences an outflow of population, and is under threat of migration, economic and, 
in the long term, political pressure from neighboring countries. A similar situation outside Transbaikalia, in other non-raw regions of Siberia. The task of development, the new development of the eastern regions of the country must be definitely solved.

\section{DISCUSSION}

This example reveals a serious problem of the concept: what should be the criteria for selecting regions-locomotives that will become sites for accelerated development?

The current "champions" such as Moscow, Samara, Tyumen and others are not necessarily the future objects of accelerated development. On the contrary, reality dictates to us the need to identify new poles of growth, the realization of new competitive advantages, spatial location and the development of new specializations. The formed map of the regions-leaders is only a spatial mirror of the primary commodity economy, which should be diversified taking into account the realities of the innovative economy, and this must be taken into account in the criteria for selecting new "locomotives".

On the other hand, the need to move to a polarized development and outstripping investments in locomotive regions can't undo the need for point support to problem regions, for example, the North Caucasus. What should be the monetary ratio of federal support for growth poles and problem regions? Becoming on the main path of polarized development, it is necessary to clearly define the set and cost of accompanying programs, which must be realized proceeding from threats of territorial integrity. Otherwise, the risks of polarized development can seriously block all the possible advantages of this productive doctrine.

The implementation of any strategy of regional development, especially revolutionary in its approaches, is extremely sensitive to the course of other actions of the federal government. Therefore, at the stage of adopting a regional strategy, it is most important to reach a consensus among developers, the economic bloc of the government, key sectoral agencies and regional elites. So, one of the basic problems that can have a decisive influence on the implementation of the strategy is the spatial dimension of sectoral federal target programs, the largest federal investment channel. Any strategy for regional development must claim to co-manage Federal Programs; otherwise it is doomed to failure. The regional distribution of Federal Programs, if they are not regulated in terms of priorities for spatial development of the country, will always dramatically distort the implementation of any most correct regional strategy. Just by virtue of its volume. The criteria for spatial development should become the basis for formulating and implementing Federal Programs.

The same is true for migration and education policy. One of the most important postulates of the regional development strategy is the need to improve migration policy in order to consolidate labor resources in Russia and create conditions for a positive balance of external migration. No less relevant is the thesis of education as an important factor in the formation of spatial and qualitative mobility of the population.

\section{CONCLUSION}

Creation and development of clusters in Russian industry is a universal decision for three important problems of the Russian economy: growth of the national industry, innovation, spatial development. This requires:

A) Consensus of federal and regional elites and key departments around the objectives and methods of industrial, innovation and spatial policy;

B) Permanent mechanism for evaluating in the federal policy "regional consequences of non-regional solutions".

It should be borne in mind that in the transition to the doctrine of polarized development there are several groups of opponents. Firstly, it is a financial and economic block of the government, which traditionally defends the possibility of maintaining an equalization policy, aimed at redistribution through the federal budget of minority incomes (donors) for the needs of the majority (recipients).

In addition, among the main opponents of the implementation of the strategy of polarized development are the regions - beneficiaries of the current redistribution policy of equalization. In addition, attempts to reorient the investment flows to the regions, naturally, will face the resistance of those regions that may lose part of the funds previously promised to them. This applies to regions that have reached certain levels in the development of federal investments. Moreover, dissatisfied may appear among donors - if their expectations to get into the locomotives of growth will be in vain. And if now the distribution of federal investments by regions is largely determined by the development of annual laws on the federal budget (that is, the distribution is not strictly set for several years ahead, and any region can claim federal funds), then according to the locomotive growth strategy will be clearly named in a special document - the General Scheme of Spatial Development of Russia. And the amount of federal funds that a region can count on will be quite severely limited in the long term.

\section{REFERENCES}

[1] Marshall Alfred, Principles of Economics, 1890 http://www.econlib.org/library/Marshall/marP.html.

[2] Porter Michael, Competition. Williams, 2005, pp. 28-29.

[3] Cluster Development and BDS Promotion. N.Y., 2016.

[4] Johnson Chalmers, MITI and Japanese Miracle. CA: Stanford University Press, 1982.

[5] Ohmae Kenichi, The Invisible Continent. N.Y., 2001.

[6] Yakovlev Andrei, Industrial Policy of the Second Generation. Expert, 2004, № 37.

[7] Granberg Alexander, Regional Development: The Experience of Russia and the European Union. Economica, 2000.

[8] Yasin Yevgeniy, Perspectives of the Russian Economy: Problems and Factors of Growth. Economic Matters, 2002, No.5. 